\title{
PENGARUH KOMPENSASI TERHADAP PRESTASI KERJA PEGAWAI PADA FAKULTAS EKONOMI UNIVERSITAS PGRI PALEMBANG
}

\author{
Tri Darmawati *)
}

\begin{abstract}
ABSTRAK
Rumusan masalah dalam penelitian ini adalah adakah pengaruh kompensasi terhadap prestasi kerja pegawai pada Fakultas Ekonomi Universitas PGRI Palembang? Sedangkan tujuan dalam penelitian ini adalah untuk mengetahui pengaruh kompensasi terhadap prestasi kerja pegawai pada Fakultas Ekonomi Universitas PGRI Palembang. Teknik analisa data yang digunakan pada penelitian ini ialah regresi linier sederhana, analisis korelasi dan uji t. Hasil output regresi linier sederhana yaitu $Y=44,517+0,487 X$ dengan koefisien korelasi sebesar nilai $r=0,516$, dan menolak hipotesis nol karena nilai t-hitung lebih besar dari pada t-tabel yaitu 4,866 >1,69 dan terima hipotesis alternatif yaitu ada pengaruh kompensasi terhadap prestasi kerja pegawai pada Fakultas Ekonomi Universitas PGRI Palembang.
\end{abstract}

Kata kunci : Kompensasi, Prestasi kerja

\section{Pendahuluan}

Berbagai cara yang dilakukan manajer dalam melaksanakan tugasnya agar tujuan perusahaan tercapai diantaranya dengan pemberian kompensasi yang wajar. Hal ini perlu dilakukan dalam rangka salah satu usaha meningkatkan prestasi kerja pegawai. Prestasi kerja pegawai penting bagi kelangsungan perusahaan karena melalui prestasi kerja yang dicapai seseorang dalam melaksanakan tugas-tugas yang dibebankan, maka perusahaan dapat mencapai tujuannya.

$$
\text { Pimpinan }
$$

perusahaan mengharapkan agar kompensasi yang diberikan dapat meningkatkan prestasi kerja pegawai. Pemberian kompensasi sangatlah penting pengaruhnya, tidak hanya meningkatkan prestasi kerja pegawai namun juga untuk meningkatkan kesejahteraan pegawai dan tentunya sangat berguna bagi pihak perusahaan dengan demikian akan tercipta hubungan harmonis antara pimpinan perusahaan dengan pegawai.

Apabila kompensasi yang ada di perusahaan dapat diterima sesuai kemajuan maka perusahaan akan dapat mempertahankan pegawai sebaliknya, jika kompensasi tidak sesuai maka pegawai akan bekerja secara tidak maksimal. Pemberian kompensasi pegawai harus mempunyai dasar yang rasional. Namun demikian, faktor emosional dan perikemanusiaan tidak boleh diabaikan. Kompensasi dikatakan penting bagi pegawai karena besar kecilnya kompensasi merupakan ukuran nilai terhadap kerja pegawai itu sendiri. Apabila pemberian kompensasi diberikan secara tepat, maka para pegawai akan memperoleh kepuasan kerja dan termotivasi untuk mencapai tujuan organisasi. Dengan demikian dapat disadari bahwa suatu kompensasi dapat meningkatkan atau menurunkan prestasi kerja pegawai.

\section{Rumusan masalah}

Agar tidak melebar pada permasalahan yang ada, maka penulis membatasi masalah yang akan dibahas hanya pada kompensasi langsung yaitu berupa gaji, insentif dan tunjangan hari raya, sedangkan prestasi kerja berupa kerjasama, tanggung jawab, kedisiplinan. Oleh karena itu dapat dirumuskan permasalahannya yaitu adakah pengaruh kompensasi terhadap 
prestasi kerja pegawai pada Fakultas Ekonomi Universitas PGRI Palembang?

\section{Tujuan Penelitian}

Penelitian ini bertujuan untuk mengetahui pengaruh kompensasi terhadap prestasi kerja pegawai pada Fakultas Ekonomi Universitas PGRI Palembang.

\section{Kajian pustaka}

Menurut

Notoatmodjo (2009:142) Kompensasi adalah segala sesuatu yang diterima oleh pegawai sebagai balas jasa untuk kerja atau pengabdian mereka. Menurut Hasibuan (2009:118) menyatakan bahwa kompensasi adalah semua pendapatan berbentuk uang, barang langsung atau tidak langsung yang diterima oleh Pegawai sebagai imbalan balas jasa yang di berikan perusahaan. Menurut William dan Davis dalam Hasibuan (2009:119) Kompensasi adalah apa yang seorang pekerja terima sebagai balasan dari pekerjaan yang di berikannya. Baik upah perjam ataupun gaji periodik didesain dan dikelola oleh bagian personalia. Menurut Andrew dalam Hasibuan (2009:119) Kompensasi adalah segala sesuatu yang dikonstitusikan atau dianggap sebagai suatu balas jasa atau ekuivalen. Berdasarkan beberapa pengertian diatas definisi kompensasi adalah semua pendapatan berbentuk uang, barang langsung atau tidak langsung yang di terima sebagai imbalan balas jasa yang adil dan layak yang di berikan perusahaan.

Tujuan sistem kompensasi menurut Notoatmodjo (2009:143-144) adalah sebagai berikut :

a) Menghargai prestasi kerja

Dengan pemberian kompensasi yang memadai adalah suatu penghargaan organisasi terhadap prestasi kerja pada pegawainya. b) Menjamin keadilan

Dengan adanya sistem kompensasi yang baik akan menjamin terjadinya keadilan diantara pegawai dalam organisasi.

c) Mempertahankan pegawai

Dengan sistem kompensasi yang baik, para pegawai akan betah atau bertahan bekerja pada organisasi itu. Hal ini berarti mencegah keluarnya pegawai dari organisasi itu untuk mencari pekerjaan yang lebih baik.

d) Memperoleh pegawai yang bermutu

Dengan sistem kompensasi yang baik akan menarik lebih banyak calon pegawai.

e) Pengendalian biaya

Dengan sistem pemberian kompensasi yang baik, akan mengurangi seringnya melakukan rekruitmen, sebagai akibat dan makin seringnya pegawai yang keluar mencari pekerjaan yang lebih baik atau menguntungkan.

f) Memenuhi peraturan - peraturan Sistem administrasi kompensasi yang baik merupakan tuntutan dari pemerintah (hukum).

Adapun tujuan dan pemberian kompensasi menurut Hasibuan (2009:121) adalah sebagai berikut :

1. Ikatan Kerjasama

Dengan pemberian kompensasi maka terjalinlah ikatan kerjasama formal antara majikan dengan pegawai, dimana pegawai harus mengerjakan tugas-tugasnya dengan baik, sedang pengusaha atau majikan wajib membayar kompensasi itu sesuai dengan yang telah disepakati.

2. Kepuasan Kerja

Dengan balas jasa, pegawai akan dapat memenuhi kebutuhan fisik, status sosial dan egoistiknya, sehingga pegawai memperoleh kepuasan kerja dari jabatannya itu. 
3. Pengadaan Efektif Jika program kompensasi ditetapkan cukup besar, maka pengadaan Pegawai yang qualified untuk perusahaan itu akan lebih mudah.

4. Motivasi

Motivasi adalah suatu faktor yang mendorong seseorang untuk melakukan suatu perbuatan tertentu. Motivasi sering pula diartikan sebagai faktor pendorong perilaku seseorang. Motivasi untuk bekerja ini sangat penting, karena akan mempengaruhi tinggi atau rendahnya produktivitas perusahaan.

5. Stabilitas Pegawai

Dengan program kompensasi atas prinsip adil dan layak serta eksternal konsistensi maka stabilitas pegawai lebih terjamin karena turn over relatif kecil.

6. Disiplin

Dengan pemberian balas jasa yang cukup besar maka disiplin pegawai semakin baik. Mereka akan menyadari serta menaati peraturanperaturan yang berlaku.

7. Pengaruh Serikat Buruh

Dengan program kompensasi yang baik, pengaruh serikat buruh dapat dihindarkan dan pegawai akan berkonsentrasi pada pekerjaannya.

8. Pengaruh Pemerintah

Jika program kompensasi itu sesuai dengan undang-undang perburuhan yang berlaku (seperti batas upah minimum) maka intervensi pemerintah dapat dihindarkan.

Kompensasi dapat diberikan dalam bentuk langsung maupun tidak langsung seperti yang dikemukakan oleh Hasibuan (2009:133) kompensasi terbagi 2 yaitu :

(1) Kompensasi langsung (Direct compesation)

Kompensasi dalam bentuk langsung terbagi menjadi : (a) Gaji, adalah balas jasa yang di bayar secara periodik kepada Pegawai tetap serta mempunyai jaminan yang pasti

(b) Upah, adalah balas jasa yang di bayarkan kepada pekerja harian dengan pedoman atas perjanjian yang di sepakati membayarnya

(c) Upah insentif, adalah tambahan balas jasa yang di berikan kepada Pegawai tertentu yang berpartisipasi atau presentasinya diatas prestasiprestasi standar perusahaan

(d) Benefit dan Service, adalah kompensasi tambahan (finansial atau non finansial) yang diberikan berdasarkan kebijaksanaan perusahaan terhadap semua Pegawai dalam usaha untuk meningkatkan kesejahteraan mereka, seperti tunjangan hari raya, uang pensiun, pakaian dinas, kafetaria, mushola, olahraga, darmawisata

(2) Kompensasi Tidak Langsung (Indirect Compensation)

Kompensasi ini dapat berupa benefit dan service yaitu kompensasi terhadap finansial maupun non finansial yang di berikan perusahaan terhadap semua Pegawai dalam usaha meningkatkan kesejahteraan mereka.

Menurut Hasibuan (2009 : 122) Azas kompensasi :

a) Azas adil

Berdasarkan kompensasi yang di bayar kepada setiap Pegawai harus di sesuaikan dengan prestasi kerja, jenis pekerjaan, resiko pekerjaan, tanggung jawab, jabatan pekerjaan dan memenuhi persyaratan internal konsistensi. 
b) Azas Layak dan Wajar

Kompensasi yang di terima pegawai dapat memenuhi kebutuhan pada tingkat normatife yang ideal.

Menurut Hasibuan (2009:94) Prestasi Kerja adalah suatu hasil kerja yang dicapai seseorang dalam melaksanakan tugas-tugas yang telah di bebankan kepadanya berdasarkan kecakapan, pengalaman, dan kesungguhan serta waktu. Menurut Manullang (2001:133), Prestasi kerja adalah suatu metode bagi manajemen untuk membuat analisa yang adil dan jujur tentang nilai bagi organisasi. Menurut Rivai (2005:14) Prestasi kerja adalah hasil atau tingkat keberhasilan seseorang secara keseluruhan dalam periode tertentu di dalam melaksanakan tugas dibanding dengan berbagai kemungkinan, seperti standar hasil kerja target atau sasaran atau kriteria yang telah ditentukan terlebih dahulu dan telah disepakati bersama. Menurut Notoatmodjo (2003:145) Menyatakan bahwa prestasi kerja adalah pencapaian kerja oleh pegawai yang ingin memiliki peluang untuk mengembangkan kemampuan kerjanya sampai ketingkat maksimal. Dari definisi yang dikembangkan para ahli diatas bahwa prestasi kerja adalah suatu hasil kerja yang dicapai seseorang dengan membandingkan hasil kerja yang telah dilakukan terdahulu dan yang dilakukan sekarang.

Menurut Hasibuan (2009: 9699), metode penilaian prestasi kerja pegawai pada dasarnya di kelompokan menjadi 2 macam, yakni sebagai berikut :

1) Metode tradisional

Metode untuk menilai prestasi kerja pegawai dan diterapkan secara tidak sistematis. Yang termasuk kedalam metode tradisional adalah a. Rating Scale

Yaitu penilaian prestasi kerja yang biasanya diisi oleh atasan langsung dengan menandai tanggapan yang paling sesuai untuk setiap dimensi pelaksanaan kerja.

b. Employee comparation

Metode ini merupakan metode penilaian yang di lakukan dengan cara membandingkan antara seorang pekerja dengan pekerja lainnya.

c. Check list

Metode ini adalah untuk mengurangi beban penilai, metode ini bisa memberikan suatu gambaran prestasi kerja secara akurat, bila daftar penilai berisi item-item yang memadai.

d. Freeform essay

Dengan metode ini seorang penilai diharuskan membuat karangan yang berkenan dengan orang/Pegawai yang sedang dinilainya.

e. Critical incident

Dengan metode ini penilai harus mencatat semua kejadian mengenai tingkah laku bawahannya sehari-hari yang kemudian dimasukan kedalam buku catatan khusus yang terdiri dari berbagai macam kategori tingkah laku bawahannya.

2) Metode modern

Metode ini merupakan perkembangan dari metode tradisional dalam menilai prestasi kerja pegawai. Yang termasuk metode modern adalah :

1) Assesment centre metode ini biasanya dilakukan dengan pembentukan tim penilai khusus.

2) Management by objective Metode ini pegawai langsung diikut sertakan dalam perumusan dan pemutusan 
persoalan

dengan

memperhatikan

kemampuan

bawahan dalam menentukan

sasaranya masing-masing yang

ditekankan pada pencapaian

sasaran perusahaan.

Manfaat penilaian prestasi kerja

dalam suatu organisasi menurut Notoatmodjo (2009:134) antara lain sebagai berikut :

1. Peningkatan Prestasi Kerja

Dengan adanya penilaian, baik manajer maupun pegawai memperoleh umpan balik, dan mereka dapat memperbaiki pekerjaan mereka.

2. Kesempatan Kerja yang adil

Dengan adanya penilaian kerja yang akurat akan menjamin setiap pegawai akan memperoleh kesempatan menempati posisi pekerjaan sesuai dengan kemampuannya.

3. Kebutuhan-Kebutuhan Pelatihan Pengembangan

Melalui penilaian prestasi kerja akan dideteksi pegawai-pegawai yang kemampuannya rendah dan kemudian memungkinkan adanya program pelatihan untuk meningkatkan kemampuan mereka.

4. Penyesuaian Kompensasi

Penilaian prestasi kerja dapat membantu para menejer untuk mengambil keputusan dalam menentukan dalam perbaikan pemberian kompensasi, gaji, bonus, dan sebagainya.

5. Keputusan-Keputusan Promosi dan Demosi

Hasil penilaian kerja terhadap pegawai dapat di gunakan untuk mengambil keputusan untuk mempromosikan pegawai yang berprestasi baik, dan demosi untuk pegawai yang berprestasi kurang baik atau jelek.

6. Kesalahan-Kesalahan Desain Pekerja
Hasil penilaian prestasi kerja dapat di gunakan untuk menilai desain kerja. Artinya hasil penilaian prestasi kerja ini dapat membantu mendiagnosis kesalahan-kesalahan desain kerja.

7. Penyimpangan-Penyimpangan Proses Rekruitmen dan Seleksi

Penilaian prestasi kerja dapat digunakan untuk menilai proses rekuitmen dan seleksi Pegawai yang telah lalu. Prestasi kerja yang sangat rendah bagi Pegawai baru adalah mencerminkan adanya penyimpangan-penyimpangan proses rekrutmen dan seleksi.

Menurut Hasibuan (2009:9596), Indikator prestasi kerja menyatakan bahwa:

a. Kesetiaan

Penilai mengukur pegawai terhadap pekerjaannya, jabatannya, dan organisasi

b. Prestasi Kerja

Penilai menilai hasil kerja kualitas maupun kuantitas yang dapat di hasilkan pegawainya tersebut di uraian pekerjaannya.

c. Kejujuran

Penilai menilai kejujuran dalam melaksanakan tugas-tugasnya memenuhi perjanjian baik bagi dirinya sendiri maupun terhadap orang lain seperti kepada bawahannya

d. Kedisiplinan

Penilai menilai disiplin pegawai dalam memenuhi peraturanperaturan yang ada dan melakukan pekerjaannya sesuai dengan instruksi yang di berikan kepadanya.

e. Kreatifitas

Penilai menilai melalui kemampuan pegawai dalam mengembangkan kreatifitasnya untuk menyelesaikan pekerjaanya sehingga bekerja lebih berdaya guna dan berhasil guna 
f. Kerjasama

Penilai menilai kesediaan Pegawai berprestasi dan bekerjasama dengan Pegawai lain secara vertikal atau horizontal di dalam maupun di luar pekerjaan sehingga hasil pekerjaan semakin baik

g. Kepemimpinan

Kepribadian penilai menilai kemampuan untuk memimpin, berpengaruh, mempunyai pribadi yang kuat, di hormati, berwibawa dan dapat memotivasi orang lain atau bawahannya untuk bekerja secara efektif.

h. Kepribadian

Penilai menilai Pegawai dari sikap prilaku, kesopanan, periang, disukai, memberi kesan menyenangkan, memperhatikan sikap yang baik.

i. Prakarsa

Penilai menilai kemampuan berpikir yang optimal dan berdasarkan inisiatif sendiri untuk menganalisis, menilai, menciptakan, memberikan alasan, mendapat kesimpulan dan membuat keputusan penyelesaian masalah yang di hadapinya

j. Kecakapan

Penilai menilai kecakapan pegawai dalam menyatukan dan menyelaraskan bermacam-macan elemen yang semuanya terlibat di dalam penyusunan kebijaksanaan di dalam situasi menajemen.

k. Tanggung Jawab

Penilai menilai kesediaan pegawai dalam mempertanggung jawabkan kebijaksanaanya, pekerjaan, dan hasil kerjanya, sarana dan prasarana yang di pergunakannya serta prilaku kerjanya.

Menurut Umar (2011:104), Hipotesis merupakan suatu perumusan sementara mengenai suatu hal. Adapun hipotesis dalam penelitian ini adalah:
Ho : Tidak ada pengaruh kompensasi terhadap prestasi kerja pegawai pada Fakultas Ekonomi Universitas PGRI Palembang.

$\mathrm{Ha}$ : Ada pengaruh kompensasi terhadap prestasi kerja pegawai pada Fakultas Ekonomi Universitas PGRI Palembang.

\section{Prosedur Penelitian}

Menurut Sugiyono (2008:58) Variabel penelitian adalah segala suatu yang berbentuk apa saja yang ditetapkan peneliti untuk dipelajari sehingga diperoleh informasi tentang hal tersebut, kemudian ditarik kesimpulannya, Adapun variabel yang digunakan dalam penelitian ini adalah:

a) Variabel bebas / independen

Variabel yang mempengaruhi atau yang menjadi sebab perubahannya atau variabel dependen. Variabel independen dalam penelitian ini adalah Kompensasi ( $\mathrm{X}$ )

b) Variabel Terikat / dependen

Varibel yang dipengaruhi atau yang menjadi akibat, karena adanya varibel bebas. variabel dependen dalam penelitian ini adalah : Prestasi kerja ( $\mathrm{Y}$ )

Tabel 1

Variabel dan Instrumen Penelitian

\begin{tabular}{|l|l|l|}
\hline No & \multicolumn{1}{|c|}{ Variabel } & \multicolumn{2}{|c|}{ Definisi operasional } \\
\hline 1 & $\begin{array}{l}\text { Kompensasi } \\
\text { Pegawai }\end{array}$ & $\begin{array}{l}\text { Semua pendapatan } \\
\text { berbentuk uang, barang } \\
\text { langsung atau tidak } \\
\text { langsung yang di terima } \\
\text { oleh Pegawai sebagai } \\
\text { imbalan balas jasa yang } \\
\text { di berikan perusahaan. }\end{array}$ \\
\hline 2 & $\begin{array}{l}\text { Prestasi kerja } \\
\text { Pegawai }\end{array}$ & $\begin{array}{l}\text { Suatu hasil kerja yang } \\
\text { dicapai seseorang } \\
\text { dengan membandingkan } \\
\text { hasil kerja yang telah } \\
\text { dilakukan terdahulu dan } \\
\text { yang dilakukan } \\
\text { sekarang. }\end{array}$ \\
\hline
\end{tabular}


Menurut Sugiyono (2008:115) Populasi adalah wilayah generalisasi yang terdiri atas Objek/subyek yang mempunyai kualitas dan karakteristik tertentu yang ditetapkan oleh peneliti untuk dipelajari dan ditarik kesimpulannya. Populasi dalam penelitian ini adalah seluruh Pegawai yang bekerja di Fakultas Ekonomi Universitas PGRI Palembang berjumlah 35 orang Pegawai. Menurut Sugiyono (2008:116) Sampel adalah bagian dari jumlah dan karakteristik yang dimiliki populasi tersebut. Oleh karena itu sampel yang diambil sebanyak 35 orang pegawai.

Menurut Sugiyono (2004:129) menyatakan bahwa data terbagi atas :

1) Data Primer merupakan data yang langsung memberikan data kepada pengumpul data tanpa melalui perantara

2) Data Sekunder merupakan sumber data yang tidak langsung memberikan kepada pengumpul data atau melalui media perantara
Ada
beberapa
teknik

pengumpulan data yang dilakukan dalam penelitian ini antara lain:

a. Angket ( kuesioner)

Adalah suatu pengumpulkan data dengan cara memberikan atau menyebarkan daftar pertanyaan/pernyataan kepada responden dengan harapan akan memberikan respon atas daftar pertanyaan tersebut.

b. Dokumentasi

Adalah pengumpulan data-data yang sudah terdokumentasi.

c. Observasi

Adalah pengumpulan data yang dilakukan melalui pengamatan dari si peneliti baik secara langsung maupun tidak langsung terhadap objek penelitiannya.

Untuk memguji kevalidan dan realibilitas dari data-data yang telah dikumpulkan maka penelitian ini masih perlu dilakukan pengujian uji validitas dan uji realibilitas. Menurut Sugiyono (2011:348) validitas berarti instrumen tersebut dapat digunakan untuk mengukur apa yang hendak diukur. Sebuah instrumen dikatakan valid apabila mampu mengukur apa yang diinginkan dan dapat mengungkap data dari variabel yang diteliti secara tepat. Cara yang dipakai dalam penguji tingkat validitas adalah analisis butir yaitu dengan cara skor-skor yang ada kemudian dikorelasikan dengan mengunakan rumus korelasi product moment sebagai berikut:

$$
r=\frac{n \cdot \sum X Y-\sum X \cdot \sum Y}{\sqrt{\left\{n \cdot \sum X^{2}-\left(\sum X\right)^{2}\right\}\left\{n \cdot \sum Y^{2}-\left(\sum Y\right)^{2}\right\}}}
$$

Keterangan :

$r=$ Koefisien korelasi validitas

$X=$ Skor item variabel bebas (Kompensasi)

$Y=$ Skor total variabel terikat (Prestasi kerja)

$n$ = Jumlah responden/sampel

Menurut Sugiyono (2011:348) instrumen yang reliabilitas berarti instrumen yang bila digunakan beberapa kali digunakan untuk mengukur objek yang sama akan menghasilkan data yang sama. Kriteria instrumen penelitian yang memiliki tingkat reliabilitas yang tinggi jika nilai koefisien yang diperoleh $>0,60$. Pengujian reliabilitas instrument dapat dilakukan dengan teknik belah dua dari Spearman brown dengan mengunakan rumus sebagai berikut:

$$
\boldsymbol{r}_{\boldsymbol{i}}=\frac{2 r b}{1+r b}
$$

Keterangan :

$\boldsymbol{r}_{\boldsymbol{i}}=$ reliabilitas internal seluruh instrumen

$\boldsymbol{r}_{\boldsymbol{b}}=$ korelasi produck moment antara belahan pertama dan kedua 
Analisis data yang digunakan dalam penelitian ini adalah Kualitatif dan Kuantitatif. Secara kualitatif digunakan dengan skala likert.

Selanjutnya untuk menganalisis pengaruh antar variabel digunakan rumus regresi linier sederhana. Analisis ini digunakan untuk melihat pengaruh kompensasi (X) terhadap prestasi kerja (Y), dengan rumus sebagai berikut:

$$
\begin{aligned}
Y^{\prime} & =a+b X \\
a & =\frac{\sum Y\left(\sum X^{2}\right)-\sum X\left(\sum X Y\right)}{n \sum X^{2}-\left(\sum X\right)^{2}} \\
b & =\frac{n \sum X Y-\left(\sum X\right)\left(\sum Y\right)}{n \sum X^{2}-\left(\sum X\right)^{2}}
\end{aligned}
$$

Keterangan :

$X$ : Kompensasi

$Y$ : Prestasi kerja

a : bilangan konstan

$b$ : koefisien regresi

Untuk mengetahui keeratan hubungan antara kompensasi terhadap prestasi kerja pegawai yang dihasilkan dengan rumus sebagai berikut (Umar,2011:131):

$$
r_{x y}=\frac{n \cdot \sum X Y-\sum X \cdot \sum Y}{\sqrt{\left\{n \cdot \sum X^{2}-\left(\sum X\right)^{2}\right\}\left\{n \cdot \sum Y^{2}-\left(\sum Y\right)^{2}\right\}}}
$$

Keterangan :

$r_{x y}$ : koefisien korelasi antara variabel $X$ dan $Y$

$\mathrm{X}$ : variabel bebas (Kompensasi)

$\mathrm{Y}$ : variabel terikat (prestasi kerja)

n : jumlah responden/sampel

Koefisien determinasi digunakan untuk mengetahui besar pengaruh faktor lain selain kompensasi
(X) terhadap prestasi kerja Pegawai $(\mathrm{Y})$.

$$
\mathrm{R}=\left(r^{2}\right) .100 \%
$$

\section{Dimana :}

$\mathrm{R}=$ Koefisien Determinasi

$r=$ Koefisien Korelasi

Menurut Sugiyono (2011: 230) uji t digunakan untuk mengetahui ada tidaknya pengaruh yang signifikan antara variabel bebas (X) dan variabel terikat $(Y)$. Ho ditolak, $\mathrm{Ha}$ diterima apabila nilai $t_{\text {hitung lebih besar dari }}$ $t_{\text {tabel }}\left(t_{\text {hitung }}>\quad t_{\text {tabel }}\right)$ maka digunakan rumus sebagai berikut :

$$
\mathrm{t} \text { hitung }=\frac{\mathrm{r} \sqrt{(\mathrm{n}-2)}}{\sqrt{\left(1-\mathrm{r}^{2}\right)}}
$$

Keterangan :

$$
\begin{array}{ll}
\mathrm{t}_{\text {hitung }} & \text { : Nilai } \mathrm{t} \\
\mathrm{r} & : \text { Koefisien korelasi } \\
\mathrm{n} & \text { : Jumlah data }
\end{array}
$$

Sedangkan untuk menentukan nilai $t_{\text {tabel }}$ digunakan kriteria :

- Taraf signifikan a 10\%

- Derajat kebebasan $(\mathrm{dk})=\mathrm{n}-2$

Ditarik kesimpulan :

1) Jika $t_{\text {hitung }}>t_{\text {tabel }}$ maka Ho ditolak dan Ha diterima

2) Jika $t_{\text {hitung }}<t_{\text {tabel }}$ maka Ho diterima dan $\mathrm{Ha}$ ditolak

\section{Hasil Penelitian}

Kompensasi diukur dengan delapan butir pernyataan. Uji coba instrumen telah dilakukan yang dipilih secara acak. Perhitugan uji validitas dilakukan dengan Korelasi Product Moment. Hasil uji validitas dari 8 butir pernyataan pada variabel kompensasi 
Tabel 2

Uji Validitas untuk Variabel Kompensai

\begin{tabular}{|c|c|c|c|c|}
\hline Item & r-hitung & r-tabel & Kriteria & Keterangan \\
\hline 1 & 0,630 & 0,482 & $r_{\text {hitung }}>r_{\text {tabel }}$ & Valid \\
\hline 2 & 0,588 & 0,482 & $r_{\text {hitung }}>r_{\text {tabel }}$ & Valid \\
\hline 3 & 0,631 & 0,482 & $r_{\text {hitung }}>r_{\text {tabel }}$ & Valid \\
\hline 4 & 0,632 & 0,482 & $r_{\text {hitung }}>r_{\text {tabel }}$ & Valid \\
\hline 5 & 0,616 & 0,482 & $r_{\text {hitung }}>r_{\text {tabel }}$ & Valid \\
\hline 6 & 0,630 & 0,482 & $r_{\text {hitung }}>r_{\text {tabel }}$ & Valid \\
\hline 7 & 0,664 & 0,482 & $r_{\text {hitung }}>r_{\text {tabel }}$ & Valid \\
\hline 8 & 0,543 & 0,482 & $r_{\text {hitung }}>r_{\text {tabel }}$ & Valid \\
\hline
\end{tabular}

Sumber : hasil pengolahan data

Berdasarkan tabel di atas semua butir pernyataan pada variabel kompensasi menunjukan $r_{\text {hitung }}>r_{\text {tabel }}$ berarti seluruh butir dapat dikatakan valid. Hal ini berarti bahwa semua butir yang dijadikan sebagai indikator terhadap variabel kompensasi telah sah untuk dijadikan sebagai alat ukur dalam penelitian ini.

Prestasi Kerja diukur dengan 8 butir pertanyaan. Uji coba instrumen telah dilakukan terhadap 15 orang responden yang dipilih secara acak. Perhitugan uji validitas dilakukan dengan Korelasi Product Moment dengan bantuan program SPSS for Windows versi 17. Hasil uji validitas dari 8 butir pernyataan pada variabel Prestasi kerja terlihat seperti pada tabel.

Tabel 3

Uji Validitas untuk Prestasi Kerja

\begin{tabular}{|c|c|c|c|c|}
\hline Item & T-hitung & $\mathrm{r}$-tabel & Kriteria & Keterangan \\
\hline 1 & 0,528 & 0,482 & $\mathrm{r}$ hitung $>\mathrm{r}_{\text {tabel }}$ & Valid \\
\hline 2 & 0,594 & 0,482 & $\mathrm{r}$ hitung $>\mathrm{r}_{\text {tabel }}$ & Valid \\
\hline 3 & 0,727 & 0,482 & $\mathrm{r}$ hitung $>\mathrm{r}_{\text {tabel }}$ & Valid \\
\hline 4 & 0,532 & 0,482 & $\mathrm{r}$ hitung $>\mathrm{r}_{\text {tabel }}$ & Valid \\
\hline 5 & 0,585 & 0,482 & $\mathrm{r}$ hitung $>\mathrm{r}_{\text {tabel }}$ & Valid \\
\hline 6 & 0,828 & 0,482 & $\mathrm{r}$ hitung $>\mathrm{r}_{\text {tabel }}$ & Valid \\
\hline 7 & 0,632 & 0,482 & $\mathrm{r}$ hitung $>\mathrm{r}_{\text {tabel }}$ & Valid \\
\hline 8 & 0,563 & 0,482 & $\mathrm{r}_{\text {hitung }}>\mathrm{r}$ tabel & Valid \\
\hline
\end{tabular}

Sumber : hasil pengolahan data

Berdasarkan tabel diatas menunjukan semua butir pernyataan pada variabel Prestasi Kerja menunjukan $r_{\text {hitung }}>r_{\text {tabel }}$ berarti seluruh butir dapat dikatakan valid. Hal ini berarti bahwa semua butir yang dijadikan sebagai indikator terhadap variabel Prestasi kerja telah sah untuk 
dijadikan sebagai alat ukur dalam penelitian ini.

Hasil perhitungan nilai reliabilitas Cronbach Alpha untuk variabel Kompensasi dengan bantuan program SPSS for Windows versi 17 dapat dilihat pada tabel berikut ini:

Tabel 4

Uji Reliabilitas untuk Variabel Kompensasi

\begin{tabular}{|c|l|l|l|}
\hline No & \multicolumn{1}{|c|}{ Variabel } & \multicolumn{1}{|c|}{$\begin{array}{c}\text { Cronbach's } \\
\text { Alpha }\end{array}$} & Kesimpulan \\
\hline 1 & Kompetensi & .866 & $\begin{array}{l}\text { Reliabel } \\
\text { Reliabel }\end{array}$ \\
\hline
\end{tabular}

Berdasarkan tabel di atas menunjukan bahwa nilai Cronbach Alpha untuk kompensasi sebesar 0.866 . Karena nilai reliabilitas lebih besar dari 0,6 maka dari 8 butir pernyataan yang dijadikan sebagai indikator pada variabel Kompensasi sudah reliabel. Sedangkan nilai Cronbach Alpha untuk prestasi kerja sebesar 0.843 . Karena nilai reliabilitas lebih besar dari 0,6 maka dari 8 butir pernyataan yang dijadikan sebagai indikator pada variabel Prestasi Kerja sudah reliabel.

Korelasi menggunakan SPSS for Windows versi 17 dapat dilihat pada tabel berikut ini :

Tabel 5

Hasil Uji korelasi

\begin{tabular}{|l|c|r|r|r|}
\hline Model & $\mathrm{R}$ & $\mathrm{R}$ Square & $\begin{array}{c}\text { Adjusted R } \\
\text { Square }\end{array}$ & $\begin{array}{c}\text { Std. Error of } \\
\text { the Estimate }\end{array}$ \\
\hline 1 & $.516^{\mathrm{a}}$ & .266 & .121 & 2.370 \\
\hline
\end{tabular}

a. Predictors: (Constant), $\mathrm{X}$

Menurut Sugiono (2005:251) Pedoman untuk memberikan interprestasikan koefisien korelasi sebagai berikut:

Tabel 6 Koefisien Korelasi

\begin{tabular}{|c|c|}
\hline $\begin{array}{c}\text { Interval } \\
\text { koefisien }\end{array}$ & $\begin{array}{c}\text { Tingkat } \\
\text { hubungan }\end{array}$ \\
\hline $0,00-0,199$ & Sangat rendah \\
$0,20-0,399$ & Rendah \\
$0,40-0,599$ & Sedang \\
$0,60-0,799$ & Kuat \\
$0,80-0,1000$ & Sangat kuat \\
\hline
\end{tabular}

Koefisien korelasi sederhana ( $r$ ) adalah 0,516 maka dapat disimpulkan bahwa terjadi hubungan yang sedang antara kompensasi terhadap prestasi kerja. koefisien determinasi ( $\mathrm{r} 2$ ) sebesar $0,266(26,6 \%)$ maka dapat disimpulkan kompensasi memberi sumbangan terhadap prestasi kerja sebesar $26,6 \%$ selebihnya sebesar $73,4 \%$ dipengaruhi oleh variabel lain yang tidak diteliti oleh peneliti.

Regresi linier sederhana menggunakan SPSS for Windows versi 17 dapat dilihat pada tabel berikut ini : 
Tabel 7

Hasil Uji Regresi Linier Sederhana

\begin{tabular}{|c|c|c|c|c|c|}
\hline \multirow[b]{2}{*}{ Model } & \multicolumn{2}{|c|}{$\begin{array}{c}\text { Unstandardized } \\
\text { Coefficients }\end{array}$} & $\begin{array}{l}\text { Standardized } \\
\text { Coefficients }\end{array}$ & & \\
\hline & B & Std. Error & Beta & $\mathrm{t}$ & Sig. \\
\hline $1 \quad$ (Constant) & 44.517 & 2.399 & & 9.292 & .000 \\
\hline$X$ & .487 & .073 & 362 & 4.866 & .000 \\
\hline
\end{tabular}

a. Dependent Variable: $Y$

Persamaan sebagai berikut :

$\mathrm{Y}=\mathrm{a}+\mathrm{b}_{\mathrm{x}}$

$Y=44,517+0,487 X$

Konstanta sebesar 44.517

artinya apabila kompensasi nilainya adalah 0 maka prestasi kerja Pegawai sebesar 44.517 Sedangkan koefisien regresi variabel kompensasi sebesar 0,487 artinya jika kompensasi mengalami kenaikan 1 maka prestasi kerja Pegawai mengalami peningkatan 0,487 koefisien bernilai positif artinya semakin tinggi kompensasi yang diberikan maka akan meningkatkan prestasi kerja Pegawai.

Setelah diperoleh hasil perhitungan koefisien korelasi antara kompensasi dan prestasi kerja maka dilakukan uji hipotesis dengan langkah-langkah pengujian berikut :

1. Menentukan Hipotesis

Ho : tidak ada pengaruh antara kompensasi dan prestasi kerja

$\mathrm{Ha}$ : ada pengaruh antara kompensasi dan prestasi kerja

2. Menentukan signifikan

Tingkat signifikan menggunakan 0,05 . Signifikan 0,05 adalah ukuran standar yang sering digunakan dalam penelitian

3. Menentukan t-hitung

Berdasarkan output yang diperoleh t-hitung sebesar 4.866

4. Menentukan t-tabel

Tabel distribusi t dicari pada $=5 \%$ (uji 2 sisi) dengan derajat kebebasan (df) $n-k-1$ atau 35-1-1 $=33$. (n) adalah jumlah kasus dan $\mathrm{k}$ adalah jumlah variabel (independen) dengan pengujian 2 sisi (signifikan $=0,05$ ) hasil diperoleh untuk t-tabel sebesar 1,69

5. Kriteria pengujian

apabila t-hitung > t-tabel maka Ho ditolak, apabila t-hitung $<$ t-tabel maka Ho diterima

8. Membandingkan t-hitung dengan ttabel

Nilai t-hitung > t-tabel $(4.866>$ 1,69) maka Ho ditolak dan $\mathrm{Ha}$ diterima artinya ada pengaruh kompensasi dengan prestasi kerja pegawai pada Fakultas Ekonomi Universitas PGRI Palembang.

Berdasarkan hasil analisis regresi linier sederhana dapat diketahui bahwa terdapat pengaruh antara variabel kompensasi $(\mathrm{x})$ dan prestasi kerja $(\mathrm{y})$ pada Fakultas Ekonomi Universitas PGRI Palembang, hal ini dapat ditunjukan dari persamaan regresi linier sederhana $Y=44,517+0,487 X$. Nilai koefisien regresi variabel kompensasi $(x)$ sebesar 0,487 artinya jika pengaruh kompensasi mengalami kenaikan 1, maka prestasi kerja (y) akan mengalami peningkatan sebesar 0,487 . Koefisien bernilai positif artinya terdapat pengaruh positif antara kompensasi dengan prestasi kerja Pegawai, semakin tinggi nilai kompensasi yang diberikan oleh kantor maka akan meningkat prestasi kerja.

Hasil koefisien korelasi sederhana $(r)$ adalah 0,516 . Koefisien determinasi ( $r 2)$ sebesar 0,266 (26,6\%) ini mengambarkan bahwa kompensasi 
mempengaruhi prestasi kerja pegawai pada Fakultas Ekonomi Universitas PGRI Palembang sebesar 26,6\% sedangkan sisanya 73,4\% dipengaruhi oleh faktor-faktor lain yang tidak diteliti dalam penelitian ini. Untuk uji hipotesis nilai t-hitung > t-tabel, ( $4,866>1,69)$. Jadi Ho ditolak $\mathrm{Ha}$ diterima, maka dapat disimpulkan bahwa ada pengaruh kompensasi terhadap prestasi kerja pegawai pada Fakultas Ekonomi Universitas PGRI Palembang.

\section{Kesimpulan dan saran}

Kesimpulan dari penelitian ini adalah:

1. Diperoleh persamaan $Y=44,517+$ $0,487 X$ artinya jika kompensasi mengalami kenaikan 1 maka prestasi kerja Pegawai (Y) mengalami peningkatan 0,487.

2. Koefisien determinasi ( $r 2$ ) sebesar $0,266(26,6 \%)$ ini mengambarkan bahwa kompensasi mempengaruhi prestasi kerja pegawai pada Fakultas Ekonomi Universitas PGRI Palembang sebesar 26,6\% sedangkan sisanya $73,4 \%$ dipengaruhi oleh faktor-faktor lain yang tidak diteliti dalam penelitian ini.

3. Hasil perhitungan t-hitung $>$ t-tabel $(4.866>1,69)$, maka Ho ditolak dan $\mathrm{Ha}$ diterima berarti bahwa ada pengaruh kompensasi $(X)$ terhadap prestasi kerja pegawai (Y) pada Fakultas Ekonomi Universitas PGRI Palembang..

Saran dari penelitian ini adalah:

1. Apabila memungkinkan sebaiknya Fakultas Ekonomi Universitas PGRI Palembang meningkatkan kompensasi yang tentu saja akan berpengaruh pada prestasi kerja Pegawai.

2. Perlu dilakukan penelitian Ianjutan untuk mencari faktor-faktor lain yang dapat menunjang prestasi kerja pegawai.

\section{Daftar Pustaka}

Handoko T.hani .2009. Manajemen. Edisi 2, BPFE,Yogyakarta.

Malayu SP Hasibuan. 2009. Manajement Sumber Daya Manusia, edisi Revisi, Bumi Aksara, Jakarta.

Marlina.2009. Pengaruh Kompensasi

Terhadap Prestasi Kerja Pegawai Pada PT Usaha Jaya Palembang,FE-UPGRI,Skripsi tidak dipublikasikan.

Manullang. 2008. Dasar-dasar Manajemen. Gajah mada. Yogyakarta.

Sugiyono.2005. Statistika Untuk

Penelitian. Alfabeta, Bandung .2010. Metode Penelitian

Bisnis. Alfabeta,Bandung 2011.

Metodologi

Penelitian Kuantitatif,

Kualitatif dan R\&D. Bandung: Alfabeta.

Soekidjo Notoatmojo. 2009. Pengembangan Sumber Daya Manusia, Cetakan Kartika, Penerbit PT Rineka Cipta, Jakarta.

Umar, Husein. 2011. Metode Penelitian Untuk Skripsi dan Tesis. Penerbit PT. Raja Grafindo Persada, Jakarta. 